Article

\title{
CD11c $^{-}$MHC2 $^{\text {low }}$ Macrophages Are a New Inflammatory and Dynamic Subset in Murine Adipose Tissue
}

Suzan Wetzels ${ }^{1}$, Mitchell Bijnen ${ }^{2}$, Erwin Wijnands ${ }^{3}$, José van de Gaar ${ }^{4}$, Andika Tan ${ }^{4}$, Susan Coort ${ }^{5}$, Erik A. L. Biessen ${ }^{1}$, Casper G. Schalkwijk ${ }^{4}$, Kristiaan Wouters ${ }^{4, *}$

1 Department of Pathology, Cardiovascular Research Institute Maastricht (CARIM), Maastricht University, Maastricht 6229 ER, the Netherlands

2 Department of Stromal Cell Immunobiology, Aix Marseille Univ, CNRS, INSERM, CIML, Marseille 13009, France

3 Central Diagnostic Laboratory, Maastricht Universitair Medisch Centrum MUMC+, $6229 \mathrm{HX}$, the Netherlands

4 Department of Internal Medicine, Cardiovascular Research Institute Maastricht (CARIM), Maastricht University, Maastricht 6229 ER, the Netherlands

5 Department of Bioinformatics-BiGCaT, School for Nutrition and Translational Research in Metabolism (NUTRIM), Maastricht University, Maastricht 6229 ER, the Netherlands

* Correspondence: Kristiaan Wouters, Email: kristiaan.wouters@maastrichtuniversity.nl; Tel.: +31-43-388-4233.

\section{ABSTRACT}

Background: The prevalence of obesity is rising and leads to increased morbidity and mortality. Adipose tissue inflammation, due to accumulation and activation of adipose tissue macrophages (ATMs), is a key driver of this phenomenon. Macrophages are heterogeneous cells, adapting quickly to the microenvironment, resulting in so-called M1 or M2 macrophages. In this study, we describe the dynamics and inflammatory properties of a newly identified ATM subset in obese mice.

Methods: $\mathrm{LDLR}^{-/-}$mice received a high fat diet (HFD) for 5 weeks or 16 weeks to induce obesity. Adipose tissues were isolated and immune cell

\section{G Open Access}

Received: 28 December 2019

Accepted: 08 April 2020

Published: 17 April 2020

Copyright $\odot 2020$ by the author(s). Licensee Hapres, London, United Kingdom. This is an open access article distributed under the terms and conditions of Creative Commons Attribution 4.0 International License. subsets were analyzed with flow cytometry or microarray analysis. Bone marrow transplantation (BMT) using CD45.1 and CD45.2 LDLR $^{-/-}$mice was performed to determine ATM origin.

Results: Upon HFD, there is a massive increase of ATM subsets in the adipose tissue. $\mathrm{CD} 11 \mathrm{c}^{-} \mathrm{M} 2 \mathrm{ATM}$ could be subdivided based on their MHC2 expression into $\mathrm{CD} 11 \mathrm{c}^{-} \mathrm{MHC} 2^{\text {high }}$ ATMs and previously unidentified

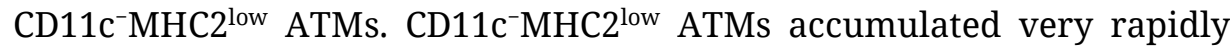
after 10 days of HFD, after which they increased even further with prolonged HFD. Microarray data showed that $\mathrm{CD} 11 \mathrm{c}^{-} \mathrm{MHC} \mathrm{2}^{\text {low }}$ ATMs resembled $\mathrm{CD} 11 \mathrm{c}^{-} \mathrm{MHC} 2^{\text {high }}$ ATMs in the steady state, but became more inflammatory during development of obesity. In vitro stimulation of bone 
marrow-derived macrophages with palmitate, abundantly present in HFD, resulted in the induction of the $\mathrm{CD} 11 \mathrm{c}^{-} \mathrm{MHC} 2^{\text {low }}$ phenotype.

Conclusions: Among M2 macrophages, a novel pro-inflammatory subset of macrophages was found based on their low level of MHC2 expression. This subset may play a role in the development of adipose tissue inflammation.

KEYWORDS: adipose tissue macrophages; MHC2; CD11c; visceral adipose tissue; flow cytometry; bone marrow transplantation; free fatty acids

\section{ABBREVIATIONS}

ATMs, adipose tissue macrophages; BMDMs, bone marrow-derived macrophages; LCM, L929 cell conditioned medium; HFD, high fat diet; VAT, visceral adipose tissue; SVF, stromal vascular fraction; OVA, ovalbumin; T2D, type 2 diabetes; FFAs, free fatty acids; PA, palmitate; OA, oleate; LDLR, low-density lipoprotein receptor

\section{INTRODUCTION}

The ever-rising prevalence of obesity represents one of the major problems in modern health care and healthy aging. Obesity predisposes to "cardiometabolic" diseases like type 2 diabetes (T2D) [1], nonalcoholic fatty liver disease (NAFLD) [2], and to atherosclerotic plaque formation and vascular dysfunction leading to cardiovascular disease (CVD) [3]. Together, these conditions account for the majority of morbidity and mortality in the world. It is now widely accepted that inflammation induced by adipose tissue macrophages (ATMs) is a key driver of these conditions [4-7]. Indeed, accumulation of ATMs is causally linked to the development of insulin resistance leading to impaired glucose homeostasis and T2D, in turn contributing to hepatic and vascular complications [6]. Moreover, ATMs directly cause immune cell recruitment from the bone marrow leading to inflammation in the liver and worsening NAFLD, irrespective of insulin resistance [8]. Thus, adipose tissue inflammation and ATM accumulation are central drivers of cardiometabolic diseases. Despite the existing experimental knowledge about the role of adipose tissue inflammation, targeting the inflammatory component of obesity in humans remains unsuccessful [4].

Macrophages display a high degree of plasticity depending on stimuli from their environment. Classically activated (M1) ATMs are proinflammatory and accumulate in expanding adipose tissue, causing inflammation [6]. On the other end of the spectrum, alternatively activated (M2) ATMs are anti-inflammatory and protect against the development of cardiometabolic diseases [6]. The presence of CD11c on the surface of human and mouse ATMs is discriminative for M1 ATMs and the accumulation of $\mathrm{CD}_{11 \mathrm{c}^{+}}$ATMs correlates with insulin resistance [9]. The M1/M2 dogma relies mainly on in vitro data and scientists start to appreciate that this subdivision is a vast oversimplification of tissue 
macrophage diversity in vivo [5]. The microenvironment of obese adipose tissue is different than lean adipose tissue. It is known that the expression of cytokines and chemokines is increased in hypertrophied adipocytes. Moreover, free fatty acids (FFAs) are increased in the microenvironment of the obese adipose tissue. Oleate (OA) is the most abundant FFA in human adipose tissue, whereas palmitate (PA) is the second most abundant [10]. Importantly, circulatory FFA levels are elevated in obesity [11,12]. This could imply that the microenvironment, FFAs in particular, have the potential to affect macrophage phenotype in vivo during obesity.

In this study, we assess the ATM subsets and their origin in $\mathrm{LDLR}^{-/-}$mice after high fat diet (HFD). The $\mathrm{LDLR}^{-/-}$mouse model lacks the low density lipoprotein (LDL) receptor which is responsible for the uptake of LDL from the circulation into tissue. Due to the knockout of LDLR, LDLR ${ }^{-/-}$mice on HFD will develop obesity with elevated levels of lipids in their circulation making it an excellent model to study the metabolic syndrome. Here, we discovered a previously undescribed ATM subset: CD11 ${ }^{-}$MHC2 $2^{\text {low }}$ ATMs. We unraveled the characteristics of this novel ATM subset and investigated the potential role of FFAs in shifting macrophages towards this subset.

\section{MATERIALS AND METHODS}

\section{Animal Studies}

High fat diet

C57BL/6 LDLR ${ }^{-/-}$mice (in house breeding colony, Maastricht University) were fed a high fat diet (HFD, 60\% of kcal from fat, Research diets, New Brunswick USA) for 5 weeks $(n=7)$ or 16 weeks $(n=7)$ with their controls on a matched control diet (Research diets, New Brunswick USA) for respectively $5(n=7)$ or 16 weeks $(n=7)$. LDLR $^{-/-}$mice develop hyperlipidemia and due to the high fat content in the diet become obese and display insulin resistance [13], resulting in an excellent model to study the metabolic syndrome. After the HFD, the mice were sacrificed by $\mathrm{CO}_{2}$ inhalation and visceral adipose tissue (vAT) was isolated for flow cytometry analysis.

\section{Clodronate liposome depletion of ATMs}

C57BL/6 LDLR ${ }^{-/-}$mice were fed a HFD for 16 weeks. Two days prior to sacrifice, the mice $(n=3)$ were intraperitoneally injected with $115 \mathrm{mg} / \mathrm{kg}$ clodronate liposomes (Clodronate liposomes.com, Amsterdam, the Netherlands). After sacrifice, the vAT was isolated for flow cytometry analysis.

\section{Bone marrow transplantation}

C57BL/6 $\mathrm{LDLR}^{-/-}$CD45.2 acceptor mice (in house breeding colony, Maastricht University) were lethally irradiated with two doses of $6 \mathrm{~Gy}, 24 \mathrm{~h}$ apart. C57BL/6 LDLR ${ }^{-/-}$CD45.1 donor mice (in house breeding colony, 
Maastricht University) were sacrificed by carbon dioxide inhalation followed by cervical dislocation. Subsequently, bone marrow was isolated from femur and tibia, pooled and dissolved in RPMI medium (Gibco ${ }^{\circledR} 1640$, Carlsbad, CA, USA) supplemented with heparin (Leo Pharma, Ballerup, Denmark) at a concentration of $50 \times 10^{6}$ cells $/ \mathrm{mL}$. Ten million donor bone marrow cells were injected in the tail vein of each acceptor mouse. Acceptor mice received $100 \mathrm{mg} / \mathrm{mL}$ Neomycin (Gibco, Carlsbad, CA, USA) and 60000 units/mL Polymyxin (p4932, Sigma-Aldrich, St. Louis, MO, USA) antibiotics in their drinking water 1 week before and 3 weeks after bone marrow transplantation. After 6 weeks recovery, mice were given either a HFD for 10 days ( $n=6$ ) or 5 weeks $(n=7)$, or a control diet for 5 weeks ( $n=$ 6). Subsequent to the diet, the mice were sacrificed by carbon dioxide inhalation followed by cardiac puncture and vAT was isolated for flow cytometry analysis.

\section{Sorting of ATM subsets}

C57BL/6 LDLR $\mathrm{LD}^{-/}$mice were fed a HFD for 16 weeks $(n=12)$ or a control diet $(n=18)$. Mice were sacrificed by $\mathrm{CO}_{2}$ inhalation, vAT was isolated for cell sorting using the flow cytometry staining panels. The ATMs were

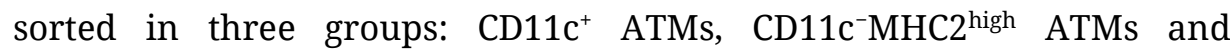
CD11 ${ }^{-}$MHC2 ${ }^{\text {low }}$ ATMs, using the FACS Aria (BD Biosciences, San Jose, CA, USA). ATMs from the vAT of $n=4$ HFD mice were pooled and ATMs from the vAT of $n=6$ control mice were pooled to create 3 pooled samples in order to gain sufficient amount of RNA to conduct the microarray analysis. The details of the amount of cells used for RNA extraction is presented in Supplemental Table S1.

\section{OVA uptake by ATM subsets}

C57BL/6 $\mathrm{LDLR}^{-/-}$mice were fed a HFD for 5 weeks $(n=4)$ or a control diet $(n=4)$. One hour prior to sacrifice, the mice received an intraperitoneal injection with $2.5 \mu \mathrm{g}$ DQ-OVA (Life Technologies, Carlsbad, CA, USA). Mice were sacrificed by $\mathrm{CO}_{2}$ inhalation and vAT was isolated to determine the DQ-OVA positive ATM subsets using flow cytometry. All performed procedures were approved by the Committee of Animal Welfare of Maastricht University (2012-20, date approved: 2/13/2012; 2012164, date approved: 3/14/2012; 2013-092, date approved: 12/01/2013; 2014059, date approved: 10/22/2014).

\section{Microarray}

RNA from sorted ATMs was isolated and 3 ng total RNA was amplified using the Ovation PicoWTA system V2 (NuGEN, Leek, the Netherlands). Afterwards, SPIA cDNA was purified using Agencourt RNAClean XP beads (Beckman Coulter, Brea, CA, USA) and $2.8 \mathrm{mg}$ was fragmented and labeled using the Encore Biotin module (NuGEN). All labeled samples were hybridized to Mouse Gene 2.1 ST arrays (Affymetrix, Santa Clara, CA, USA). 
Washing, staining and scanning was performed using the GeneTitan Hybridization, Wash, and Stain Kit for WT Array Plates, and the GeneTitan Instrument (Affymetrix, Santa Clara, CA, USA). Data were normalized using GC-RMA normalization using Expression console software. Quality control was performed and all samples passed the quality control test. Next, data was analyzed using transcriptome analysis console v2.0 from Affymetrix using $t$-test from the R/Bioconductor package Limma. Data was corrected for multiple testing using false discovery rate (FDR). Gene ontology enrichment analysis was performed using The Database for Annotation, Visualization and Integrated Discovery (DAVID) v6.8 (https://david.ncifcrf.gov/). Pathway annotations were validated using WikiPathways (https://www.wikipathways.org/) and Reactome (https://reactome.org/). Data is presented as fold change (FC) in expression level compared to LFD fed mice. Genes showing fold changes of at least 1.50 and a $P$-value of less than 0.05 were considered differentially regulated.

\section{Cytokine Measurements}

Cytokines were measured, as described previously [14], in the plasma of $\mathrm{LDLR}^{-/-}$mice after $5(n=7)$ and $16(n=7)$ weeks of HFD using the V-plex multi-array electrochemiluminescense detection platform of MesoScaleDiscovery (MesoScaleDiscovery, Rockville, MD, USA) following manufacturer's instruction.

\section{Culturing of Murine Bone Marrow-Derived Macrophages and Stimulation with Fatty Acids}

C57BL/6J mice were sacrificed by cervical dislocation and femur and tibia were isolated. Femur and tibia were flushed with PBS through a 70 $\mu \mathrm{M}$ filter to obtain a single cell suspension. After centrifuging, the cells were resuspended in complete medium: RPMI 1640 GlutaMAX (Gibco, Carlsbad, CA, USA), supplemented with 1\% glutamine penicillin/streptomycin, 10\% heat-inactivated fetal calf serum (Greiner Bio-One, Kremsmünster, Austria) and 15\% L929 cell conditioned medium (LCM). Cells were cultured for 7 days to allow differentiation into bone marrow-derived macrophages (BMDMs).

Fatty acids PA (5 mM, Sigma-Aldrich, Saint Louis, MO, USA) and OA (50 mM, Sigma-Aldrich, Saint Louis, MO, USA) were dissolved in 96\% ethanol. Next, the solutions were saponified by adding $\mathrm{NaOH}$ at a 5:1 (PA:NaOH) or 1:2 (OA:NaOH) ratio. The saponified solutions were evaporated under $\mathrm{N}_{2}$ at $37^{\circ} \mathrm{C}$. Boiling MQ was added to resuspend the saponified fatty acids. The fatty acids were dissolved in RPMI 1640 (Gibco, Carlsbad, CA, USA) containing 1\% BSA (Sigma-Aldrich), resulting in solutions of $500 \mu \mathrm{M}$ PA and $500 \mu \mathrm{M}$ OA. BMDMs were stimulated with $50 \mu \mathrm{M}$ PA, $50 \mu \mathrm{M}$ OA and a combination of $50 \mu \mathrm{M}$ PA and $50 \mu \mathrm{M}$ OA for $16 \mathrm{~h}$. After stimulation, BMDMs were washed with PBS and harvested for RNA isolation using TriReagent (Sigma-Aldrich, Saint Louis, MO, USA) or flow cytometry. 


\section{RNA Isolation and RT-qPCR}

RNA from BMDMs was isolated using TriReagent (Sigma-Aldrich, Saint Louis, MO, USA) and cDNA was synthesized using the iScript ${ }^{\mathrm{TM}}$ cDNA Synthesis Kit (Bio-rad, Hercules, CA, USA) according to manufacturer's instructions. RT-qPCR was performed using the $2 \mathrm{X}$ SensiMix ${ }^{\mathrm{TM}} \mathrm{SYBR}^{\circledR}$ \& Fluorescein Kit (Bioline, London, UK). The $\Delta \Delta \mathrm{Ct}$ method was used to determine the gene expression of the target genes CD11c (FW: CTGGATAGCCTTTCTTCTGCTG, RV: GCACACTGTGTCCGAACTCA) and MHC2 (FW: CCTGGTGACTGCCATTACCT, RV: GTAGCACTCGCCCATGAACT), relative to the house keeping genes Cyclophilin (FW: TTCCTCCTTTCACAGAATTATTCCA, RV: CCGCCAGTGCCATTATGG) and Beta-2 microglobulin (FW: CTTTCTGGTGCTTGTCTCACTGA, RV: GTATGTTCGGCTTCCCATTCTC). The CFX96 Touch ${ }^{\text {TM }}$ Real-Time PCR Detection System (Bio-rad, Hercules, CA, USA) was used for thermal cycling and fluorescence detection.

\section{Flow Cytometry}

vAT was incubated for $30 \mathrm{~min}$ at $37^{\circ} \mathrm{C}$ with collagenase mix containing collagenase XI (1200 U/mL, Sigma-Aldrich, Saint Louis, MO, USA), collagenase I (3700 U/mL, Sigma-Aldrich, Saint Louis, MO, USA) and DNAse I (6760 U/mL, Sigma-Aldrich, Saint Louis, MO, USA) to digest the tissue. Samples were shaken every $5 \mathrm{~min}$ to improve the digestion. Subsequently, samples were filtered using $70 \mathrm{uM}$ filters (2017500, BD Biosciences, CA, USA), centrifuged for $5 \mathrm{~min}$ at $1200 \mathrm{RPM}$ and the floating adipocyte fraction was removed. The remaining pellet contained the stromal vascular fraction (SVF) and the erythrocytes were eliminated using a lysis buffer $(\mathrm{pH}=7.3)$ containing $\mathrm{NH}_{4} \mathrm{Cl}(8.26 \mathrm{~g} / \mathrm{L}), \mathrm{KHCO}_{3}(1 \mathrm{~g} / \mathrm{L})$ and EDTA $(0.037$ $\mathrm{g} / \mathrm{L})$. After $1 \mathrm{~min}$ incubation with lysis buffer, samples were washed with PBS. Fc-blocking solution (16-01661, eBioscience, Vienna, Austria) containing CD16/CD32 antibodies was added to prevent nonspecific binding of antibodies and samples were incubated for $30 \mathrm{~min}$. Subsequently, samples were stained with two antibody mixes for $30 \mathrm{~min}$. Mix 1 consisted of CD45, CD45.1, CD45.2, NK1, CD11b, Ly6G, F4/80, CD3, CD19, CD11c and MHC2 (eBioscience, Vienna Austria), and was used to detect the different subpopulations of adipose tissue macrophages in the adipose tissue. The second mix consisted of CD45, CD45.1, CD45.2, CD3, NK1, Ly6G, CD11b, CD68, CD8 and CD4 (eBioscience, Vienna, Austria), and was used to detect granulocytes, monocytes, NK-cells and T-cells. Samples were washed twice with FACS buffer (10 $\mathrm{mM} \mathrm{NaN}_{3}, 0.5 \%$ BSA in PBS) and measured using FACS Canto II flow cytometer (BD Biosciences, San Jose, CA, USA). Data was analyzed using FACS Diva software version 6.12. The flow cytometry plots showing the gating strategy are depicted in Supplemental Figure S1. In short, CD45 staining was used to select the immune cells from singlet live cells in the adipose tissue. B-cells, T-cells, NK cells and granulocytes were excluded using B220, NK1, CD3 and Ly6G 
staining. Next, CD11b and F4/80 were used to select $\mathrm{CD}_{11 \mathrm{c}^{-}} \mathrm{ATM}$ and

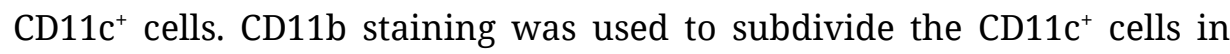
CD11 $c^{+} \mathrm{CD} 11 \mathrm{~b}^{\text {high }}$ ATMs and $\mathrm{CD} 11 \mathrm{c}^{+} \mathrm{CD} 11 \mathrm{~b}^{\text {low }}$ dendritic cells. CD11 $\mathrm{c}^{-}$cells

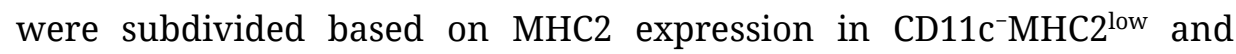
CD11c-MHC2 ${ }^{\text {high }}$ ATMS.

vAT of mice injected with DQ-OVA was processed using collagenase mix and erythrocyte lysis buffer as described above. Cells were incubated with Fc blocking solution (16-01661, eBioscience, Vienna Austria) for $15 \mathrm{~min}$. Next, cells were stained with CD45, NK, CD11b, Ly6G, Ly6C, CD3, CD19, CD11c, MHC2, MerTK and F4/80 (eBioscience, Vienna, Austria) for $30 \mathrm{~min}$. Excess antibody was removed by washing twice with FACS buffer and samples were measured using FACS Canto II flow cytometer (BD Biosciences, San Jose, CA, USA). Data was analyzed using FACS Diva software version 6.12. Gating strategy was applied as described above (Supplemental Figure S1).

BMDMs stimulated with fatty acids were harvested using 10 mM EDTAPBS. Fc-blocking was performed using CD16/CD32 antibodies (16-01661, eBioscience, Vienna, Austria) for $15 \mathrm{~min}$. BMDMs were stained with F4/80, CD11c and MHC2 (eBioscience, Vienna, Austria) for $30 \mathrm{~min}$. Excess antibody was removed by washing twice with FACS buffer and samples were measured using FACS Canto II flow cytometer (BD Biosciences, San Jose, CA, USA). Data was analyzed using FACS Diva software version 6.12. The following gating strategy was used: the singlet's were determined using forward scatter-area (FSC-A) and FSC-height (FSC-H), and using the side scatter-width (SSC-W) and SSC-height (SSC-H). Next, the live fraction was determined based on FSC-A and SSC-area (SSC-A). The cells positive for $\mathrm{F} 4 / 80$ were gated and these were used to subdivide into $\mathrm{CD} 11 \mathrm{c}^{+}$and CD11 $\mathrm{c}^{-}$fraction of BMDMs. The $\mathrm{CD} 11 \mathrm{c}^{-}$fractions was used to determine the $\mathrm{CD} 11 \mathrm{c}^{-} \mathrm{MHC} 2^{\text {high }}$ and $\mathrm{CD} 11 \mathrm{c}^{-} \mathrm{MHC} 2^{\text {low }} \mathrm{BMDMs}$.

\section{Statistical Analysis}

All data is presented as mean \pm SEM. Data was analyzed with GraphPad Prism version 6 using Mann Whitney $t$-test and unpaired student $t$-test to compare two groups, and one-way ANOVA with Tukey's multiple comparison test or Dunnett's multiple comparison test to compare multiple groups. A $p<0.05$ was considered significant.

\section{RESULTS}

CD11C $^{-}$MHC2 $^{\text {low }}$ Adipose Tissue Macrophages Are a Novel and Dynamic Subpopulation of Macrophages in the Adipose Tissue of LDLR $^{-/-}$Mice

vAT isolated from $\mathrm{LDLR}^{-/-}$mice receiving a HFD for 16 weeks was prepared for flow cytometry and stromal vascular cells were assessed for F4/80, the classical murine macrophage marker and CD11c, which is discriminative for M1 ATMs [15]. F4/80 $0^{\text {high }} \mathrm{CD} 11 \mathrm{c}^{-}$cells are considered M2 
ATMs. M1 macrophages expressed high levels of MHC2 while M2 ATMs could be further subdivided based on their degree of MHC2 expression into $\mathrm{MHC} 2^{\text {high }}$ and $\mathrm{MHC}^{\text {low }} \mathrm{M} 2 \mathrm{ATMs}$ (Figure $1 \mathrm{~A}, \mathrm{~B}$ ). The gating strategy to discriminate between the three ATM subsets is shown in Supplemental Figure S1. To assess the phagocytic properties of the CD11c ${ }^{-}$MHC2 ${ }^{\text {low }}$ ATM subset and confirm the macrophage phenotype of the subsets, we fed $\mathrm{LDLR}^{-/-}$mice a HFD for 10 weeks and the phagocytosing macrophages were depleted two days prior to sacrifice with clodronate liposomes [16]. All three ATM subsets, $\mathrm{F} 4 / 80^{\text {high }} \mathrm{CD} 11 \mathrm{c}^{-} \mathrm{MHC} 2^{\text {low }}, \mathrm{F} 4 / 80^{\text {high }} \mathrm{CD} 11 \mathrm{c}^{-} \mathrm{MHC} 2^{\text {high }}$, and $\mathrm{F} 4 / 80^{\text {int }} \mathrm{CD} 11 \mathrm{c}^{+} \mathrm{Cd} 11 \mathrm{~b} \mathrm{~b}^{\text {high }}$ cells were decreased in the vAT of obese $\mathrm{LDLR}^{-/-}$mice whereas the $\mathrm{F} 4 / 80^{-} \mathrm{CD} 11 \mathrm{c}^{+} \mathrm{CD} 11 \mathrm{~b}^{\text {low }}$ dendritic cells remained unaffected showing the phagocytic capacity of the three ATM subsets and confirming their macrophage identity (Supplemental Figure S2). $\mathrm{F} 4 / 80^{-} \mathrm{CD} 11 \mathrm{c}^{+} \mathrm{CD} 11 \mathrm{~b}^{\text {low }}$ cells have previously been described to possess a dendritic cell signature [17].

As expected, HFD induced an expansion of the CD11 ${ }^{+}$M1 ATM subset in vAT of $\mathrm{LDLR}^{--}$mice (Figure 1C). The CD11c ${ }^{-} \mathrm{MHC}{ }^{\text {high }}$ M2 ATM subset increased in the vAT after 5 weeks of HFD and remained elevated during prolonged HFD (Figure 1D). The CD11 ${ }^{-} \mathrm{MHC}^{\text {low }}$ ATM subset increased in the vAT during aging of the mice, however upon HFD, this subset expanded greatly (2.7 fold) (Figure 1E) suggesting that this subset has an important role during obesity. The CD11c ${ }^{-} \mathrm{MHC}^{\text {high }} \mathrm{M} 2$ ATM subtype is also affected by aging as 16 weeks of control diet resulted in increased CD11 ${ }^{-}$MHC2 ${ }^{\text {high }}$ subset in the vAT which was unaffected by HFD (Figure 1D). Five week high fat feeding also resulted in increased levels of monocytes and dendritic cells in the vAT of $\mathrm{LDLR}^{-/-}$mice whereas 16 weeks of HFD resulted in a decrease of NK and CD4 ${ }^{+} \mathrm{T}$-cells (Supplemental Figure S3). Aging also led to an increase of dendritic cells and $\mathrm{CD} 4^{+} \mathrm{T}$-cells in the vAT on control diet (Supplemental Figure S3). Similar results for immune cell subsets were found in the subcutaneous adipose tissue of $\mathrm{LDLR}^{-/-}$mice after 5 and 16 weeks of HFD (Supplemental Figure S4). Also in the scAT, aging of the $\mathrm{LDLR}^{-/-}$mice resulted in increased levels of $\mathrm{CD} 11 \mathrm{c}^{-} \mathrm{MHC} 2^{\text {high }}$ ATMs, granulocytes and $\mathrm{CD} 4^{+} \mathrm{T}$-cells (Supplemental Figure S4). Immune cell subsets in the blood, spleen and bone marrow were not affected by 5 and 16 weeks of HFD (data not shown). In addition, we confirmed the presence of $\mathrm{CD} 11 \mathrm{c}^{-} \mathrm{MHC} 2^{\text {low }}$ and $\mathrm{CD} 11 \mathrm{c}^{-} \mathrm{MHC}^{\text {high }}$ ATM subsets in the vAT of wild type C57BL/6J mice and observed a similar increase upon a HFD compared as in $\mathrm{LDLR}^{-/-}$mice (data not shown). 


\section{A}
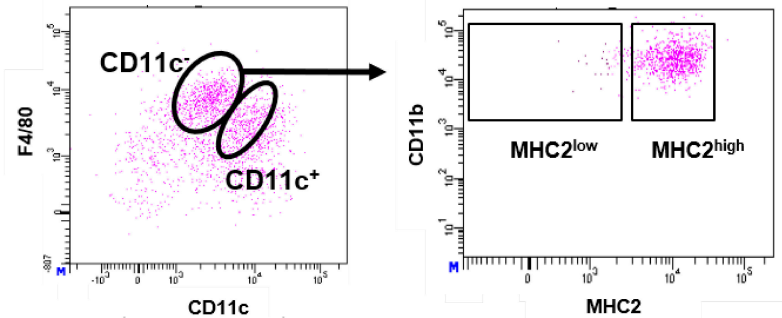

B
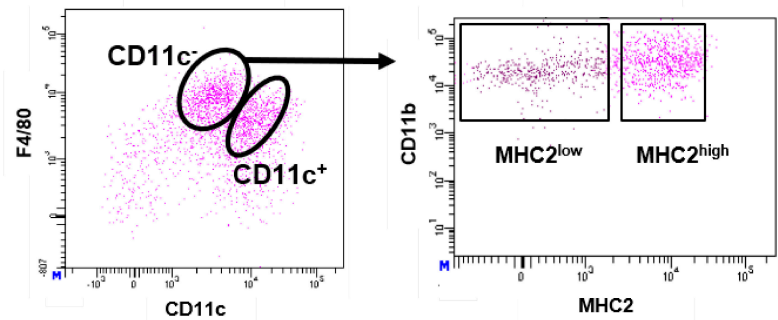

C

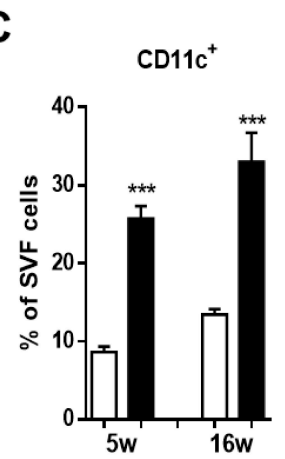

D CD11C ${ }^{-} \mathrm{MHC}^{\text {high }}$

$\mathrm{E}$

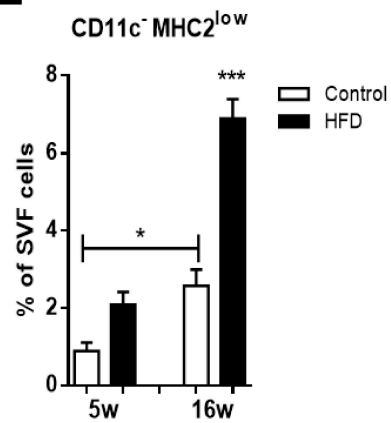

Figure 1. CD11c $^{-} \mathrm{MHC2} 2^{\text {low }}$ macrophages are a novel and dynamic adipose tissue macrophage population. Flow cytometry analysis of vAT from (A) lean and (B) obese LDLR $^{-1-}$ mice shows that within CD11 $\mathrm{C}^{-}$macrophages, two subsets can be identified based on surface expression of MHC2. Inducing obesity by feeding mice a HFD induces accumulation of (C) CD11 $\mathrm{c}^{+}$macrophages, (D) CD11c $\mathrm{C}^{-} \mathrm{MC} \mathrm{2}^{\text {high }}$ and (E) CD11 $\mathrm{c}^{-} \mathrm{MHC} 2^{\text {low }}$ macrophages in the vAT of $\mathrm{LDLR}^{-/-}$mice ( $n=7 /$ group). Data is presented as mean \pm SEM and analyzed using one-way ANOVA with Tukey's multiple comparison test. ${ }^{*} p<0.05,{ }^{* *} p<0.01,{ }^{* * *} p<0.001$.

\section{CD11c $^{-}$MHC2 $^{\text {low }}$ Adipose Tissue Macrophages Are Recruited from the Bone Marrow to the Adipose Tissue during Obesity}

To investigate tissue residence time and developmental origin of CD11 $\mathrm{C}^{-}$MHC2 ${ }^{\text {low }}$ ATMs, CD45.1 bone marrow was transplanted to lethally irradiated CD45.2 $\mathrm{LDLR}^{-/-}$mice, resulting in spontaneous repopulation of the bone marrow. After six weeks of recovery, the transplanted $\mathrm{LDLR}^{-1-}$ mice of the 5 weeks HFD group started receiving diet (Figure 2A). Body weight of these mice increased until $120 \%$ of their starting weight after 5 weeks HFD. The transplanted $\mathrm{LDLR}^{-/-}$mice receiving 10 days HFD group were on control diet until 10 days before their sacrifice. After switching to a HFD, body weight increased rapidly (Figure 2A). With flow cytometry, ATMs from either acceptor (tissue-resident; CD45.2) or donor (bone marrow; CD45.1) origin were determined. 

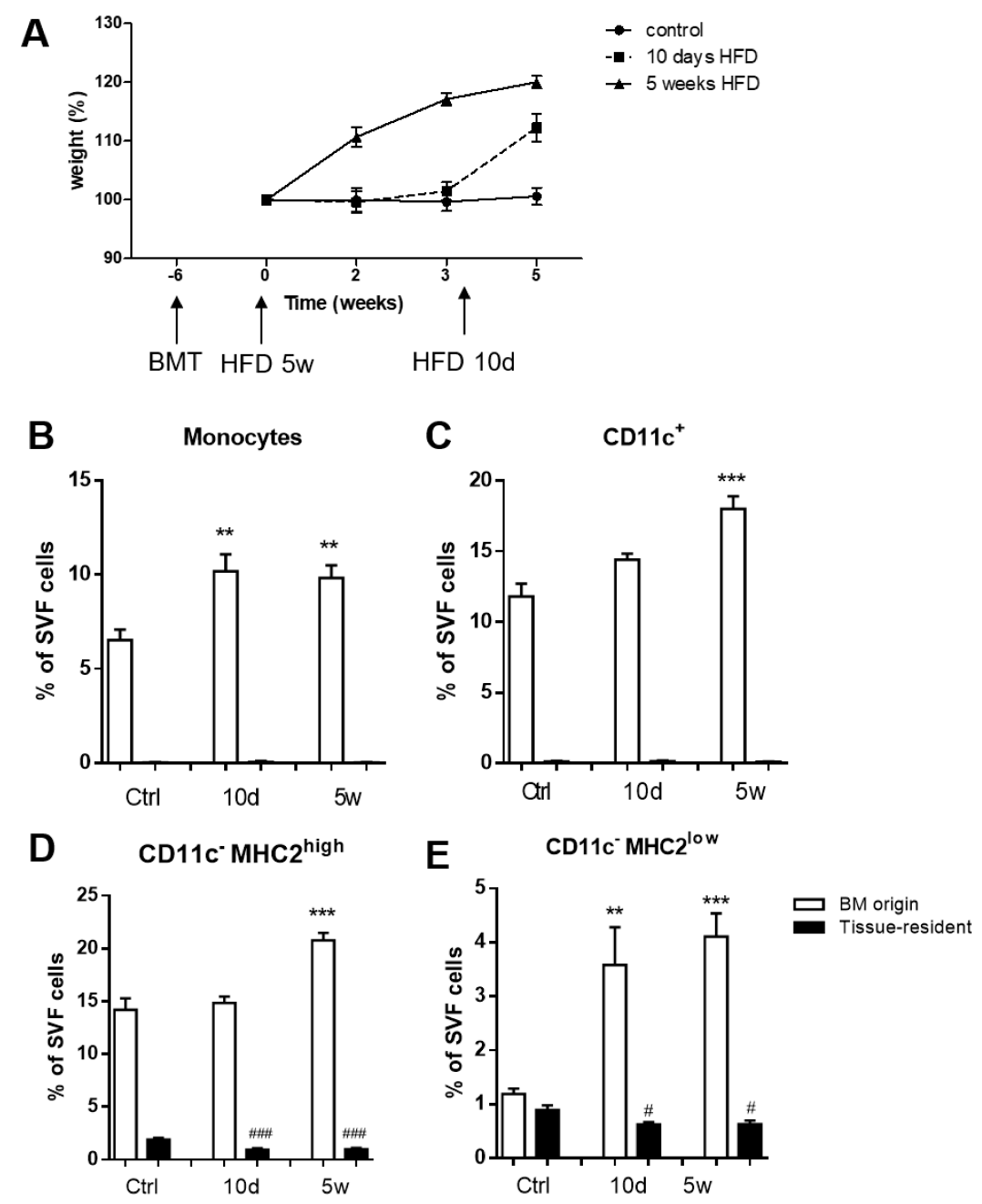

Figure 2. Infiltrating $\mathrm{CD}_{11 \mathrm{c}^{-}} \mathrm{MHC}{ }^{\text {low }}$ macrophages originate from bone marrow. (A) $\mathrm{LDLR}^{-/-} \mathrm{CD} 45.2$ mice were lethally irradiated and transplanted with $\mathrm{LDLR}^{-/-} \mathrm{CD} 45.1$ bone marrow. Mice were sacrificed after 10 days $(n=6)$ or 5 weeks $(n=7)$ of HFD. Age-matched animals on a control diet were sacrificed 11 weeks post-transplantation $(n=6)$. vAT was analyzed using flow cytometry. Graph shows setup and body weight during the experiment. White bars represent cells from bone marrow (CD45.1) origin and black bars represent tissue-resident (CD45.2) cells. (B) 10 days of high fat feeding results in the accumulation of monocytes from bone marrow origin in vAT and this increase remains stable up to 5 weeks after HFD. (C) CD11 $\mathrm{c}^{+}$ATMs tended to be increased already after 10 days of HFD, and continued to increase after 5 weeks. (D) $\mathrm{CD}_{11 \mathrm{C}^{-}} \mathrm{MHC}^{\text {high }}$ ATMs were only increased after 5 weeks of HFD, probably originating from bone marrow. (E) CD11 $\mathrm{c}^{-} \mathrm{MHC} 2^{\text {low }}$ ATMs showed comparable distribution of bone marrow versus resident cells.

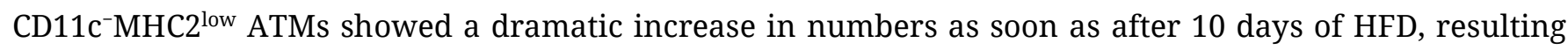
from bone marrow recruitment. Data is presented as mean \pm SEM and analyzed using one-way ANOVA with Dunnett's Multiple Comparison Test. ${ }^{*}$ significance between BM origin cells due to HFD; ${ }^{* *} p<0.01,{ }^{* * *} p<$ 0.001, \# significance between tissue-resident cells due to HFD; \# $p<0.05$, \#\#\# $p<0.001$.

In steady state, we observed a complete replacement of monocytes and CD11 $\mathrm{c}^{+}$macrophages in the vAT of $\mathrm{LDLR}^{-/-}$mice by bone marrow derived cells and virtually no tissue resident monocytes and $\mathrm{CD} 11 \mathrm{c}^{+}$macrophages remained in the vAT (Figure 2B,C). CD11 $\mathrm{c}^{-} \mathrm{MHC} \mathrm{2}^{\text {high }}$ ATMs consisted of almost $89 \%$ of cells that were of bone marrow origin, but $11 \%$ of the population remained of tissue resident origin (Figure 2D). Strikingly, $43 \%$ 
of the $\mathrm{CD}_{11 \mathrm{C}^{-} \mathrm{MHC}}{ }^{\text {low }}$ ATMs in the vAT of $\mathrm{LDLR}^{-/-}$mice after lethal irradiation remained of tissue resident origin indicating that this subset of ATMs is either more resistant to irradiation or that there is less cell turnover within this subset (Figure 2E).

Upon 10 days of HFD, monocytes were recruited from the bone marrow to the vAT of $\mathrm{LDLR}^{-/-}$mice and these levels were maintained after 5 weeks of HFD (Figure 2B). The $\mathrm{CD}_{11 \mathrm{c}^{+}} \mathrm{ATMs}$ from bone marrow origin accumulated after 5 weeks of HFD in the vAT (Figure 2C), similar as the $\mathrm{CD}_{11 \mathrm{C}^{-} \mathrm{MHC}}{ }^{\text {high }}$ ATMs (Figure 2D). The CD11 $\mathrm{c}^{-} \mathrm{MHC}^{\text {low }}$ ATM subset was rapidly increased after 10 days of HFD and remained elevated after 5 weeks of HFD as a result of bone marrow recruitment (Figure 2E).

\section{CD11c $^{-}$MHC2 $^{\text {low }}$ Adipose Tissue Macrophages Adopt an Inflammatory Phenotype during Obesity}

To determine the differentially expressed genes in $\mathrm{CD}_{11} \mathrm{c}^{+}$, $\mathrm{CD}_{11 \mathrm{C}^{-} \mathrm{MHC}} 2^{\text {low }}$ and $\mathrm{CD} 11 \mathrm{c}^{-} \mathrm{MHC} 2^{\text {high }}$ ATMs, we performed microarray expression analysis on FACS-sorted cells of these subsets. In steady-state, in $\mathrm{LDLR}^{-/-}$mice on the control diet, CD11c-MHC2 ${ }^{\text {high }}$ ATMs express 1528 genes higher and 1152 genes lower compared to CD11 $\mathrm{c}^{+}$ATMs (adjusted $p$ value $<0.05$ ). This shows the great variety between the $C D 11 \mathrm{c}^{+} \mathrm{M} 1$ and

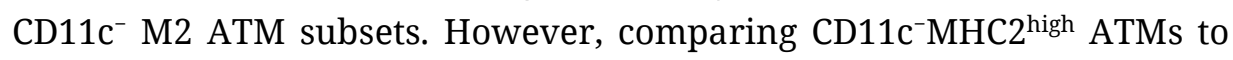
CD11 $\mathrm{c}^{-} \mathrm{MHC} 2^{\text {low }}$ ATMs, only 35 genes were expressed higher and 88 genes were expressed lower. This indicates that in basal conditions the two M2 subsets are much alike. Upon a HFD given to $\mathrm{LDLR}^{-/-}$mice, gene expression profile of all three ATM subsets change; CD11 $\mathrm{c}^{+}$M1 ATMs paradoxically gain a slightly attenuated inflammatory phenotype as they upregulate 667 genes from pathways involved in lipid transport, membrane organization and endocytosis, and downregulate 334 genes from pathways linked to phosphorylation and immune response (Figure 3A). CD11 ${ }^{-}$MHC $2^{\text {high }}$ ATMs showed upregulation of 261 genes from pathways involved in DNA replication, cell cycle and cell activation (Figure 3B). CD11c ${ }^{-} \mathrm{MHC}{ }^{\text {low }}$ ATMs seemed to exhibit highly distinct characteristics as they upregulated 273 genes involved in immune response and immune cell activation pathways (Figure 3C), the latter including a cluster of genes involved in cell mobility. Genes upregulated for the cluster cell mobility included CCL2, CCR2, CCR5 and CXCR4 (Supplemental Table S2). Genes upregulated in the cluster immune response included several genes involving the transcription factor CiiTA and histocompatibility 2 target genes (Supplemental Table S3). Since this upregulation of genes also involved antigen presentation related genes, we determined whether there is a difference in antigen uptake and processing capacity, an inflammatory characteristic of macrophages. Therefore, we explored the ability of the three ATM subsets and dendritic cells to take up and process labeled ovalbumin (DQ-OVA) after HFD, as a measure for antigen processing. The results show that only the CD11 ${ }^{-}$MHC2 ${ }^{\text {low }}$ ATM subset increases the uptake and processing of OVA during 5 weeks of HFD feeding (Figure 4A), whereas high fat feeding did 
not affect antigen processing capacity of $\mathrm{CD} 11 \mathrm{c}^{-} \mathrm{MHC} 2^{\text {high }}$ ATMs, CD11 $\mathrm{c}^{+}$ ATMs and dendritic cells (Figure 4B-D). The increased antigen processing capacity of the $\mathrm{CD} 11 \mathrm{c}^{-} \mathrm{MHC} 2^{\text {low }}$ ATMs could suggest that T-cell activation is increased in the adipose tissue of $\mathrm{LDLR}^{-/-}$mice upon HFD. However, the amount of $\mathrm{CD}^{+}$T-cells in the vAT and scAT upon 16 weeks of HFD are decreased (Supplemental Figures S3 and S4), arguing against a local activation of T-cells by these macrophages. To assess whether there were changes in the T-cell cytokine profile in the blood, we measured multiple cytokines in plasma of these mice after 5 and 16 weeks of HFD. The results showed that after 5 and 16 weeks of HFD, plasma IL-10 levels were increased (data not shown). However, the other cytokines (IFN $\gamma$, IL-12, IL2, IL-4, and IL-5), reflective of either Th1 or Th2 activation, were not affected by the HFD (data not shown). Together, these data do not support T-cell specific changes in the plasma and vAT after HFD coinciding with an

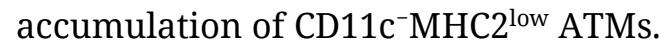

A

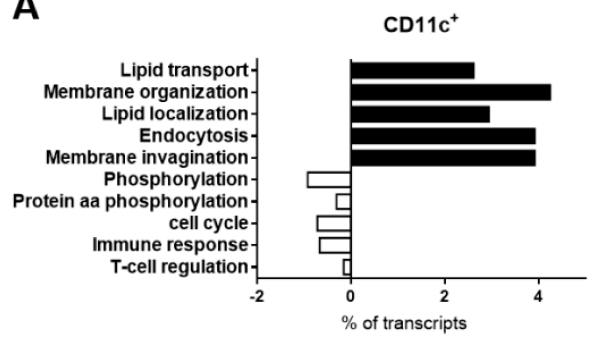

B

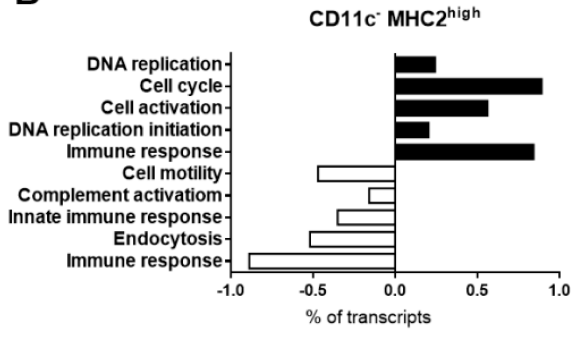

C

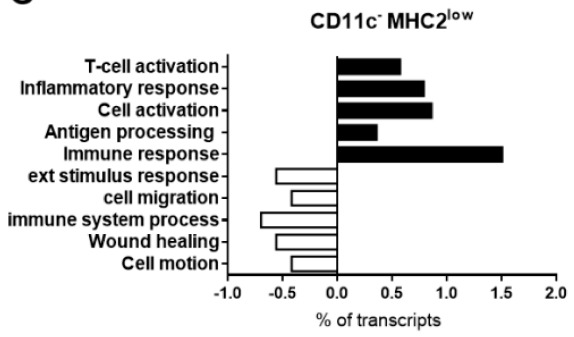

Figure 3. Microarray of the $\mathrm{CD}_{11 c^{+}}, \mathrm{CD}_{11 c^{-}} \mathrm{MHC}^{\text {high }}$ and CD11c-MHC2 ${ }^{\text {low }}$ ATMs. Using fluorescent activated cell sorting, the ATM subsets were isolated from lean (3 pooled samples from $n=6 \mathrm{LDLR}^{-/-}$ mice/sample) and obese animals (3 pooled samples from $n=4 \mathrm{LDLR}^{-/-}$mice/sample). Genes regulated by high fat feeding in the three ATM subsets were analyzed. GO annotation analysis showed diet-induced effect in (A) $\mathrm{CD} 11 \mathrm{c}^{+}$, (B) $\mathrm{CD} 11 \mathrm{c}^{-} \mathrm{MHC} 2^{\text {high }}$, and (C) CD11 $\mathrm{c}^{-} \mathrm{MHC} 2^{\text {low }}$ ATMs.
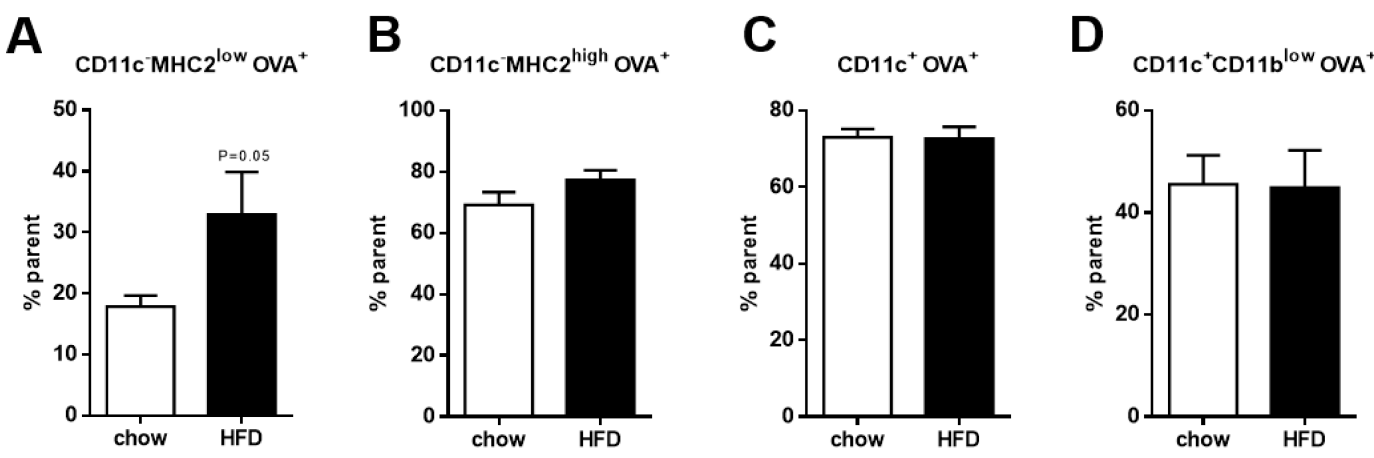

Figure 4. Antigen uptake and processing in the three subsets of ATMs and dendritic cells. Uptake and

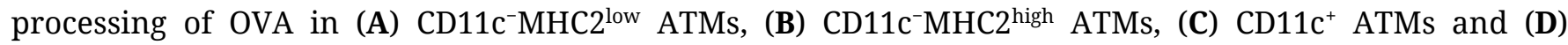
CD11 $\mathrm{c}^{+} \mathrm{CD} 11 \mathrm{~b}^{\text {low }}$ dendritic cells in the vAT of $\mathrm{LDLR}^{-/-}$mice after 5 weeks of HFD feeding ( $n=4 /$ group). Data is presented as mean \pm SEM and analyzed using Mann-Whitney $t$-test. 


\section{The CD11c ${ }^{-}$MHC2 ${ }^{\text {low }}$ Phenotype of ATMs Can Be Induced by PA and OA}

A key characteristic of obesity is the presence of elevated levels of free fatty acids (FFAs) in the adipose tissue. These FFAs include, among others, dietary fatty acids such as PA and OA which are known to have pro- and anti-inflammatory effects respectively. Previously it was revealed that lipolysis in mouse adipose tissue regulates the accumulation of macrophages in the adipose tissue [18]. Since PA and OA are the major FFA types in lard, we tested their effects on the phenotype of macrophages. BMDMs were stimulated in vitro with PA, OA and a mix of PA and OA followed by flow cytometry to determine the BMDM phenotype. The stimulation with PA and the combination of PA and $\mathrm{OA}$ induced the

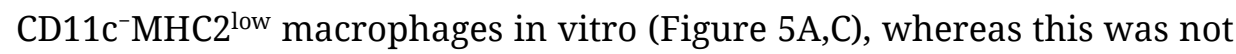
found for OA stimulation alone (Figure 5B). Our data indicate that the microenvironment of the macrophage is crucial for its phenotype and functional characteristics during obesity.

A

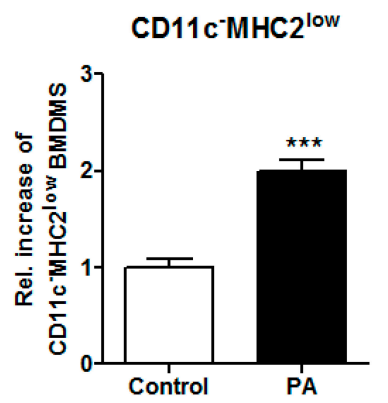

B

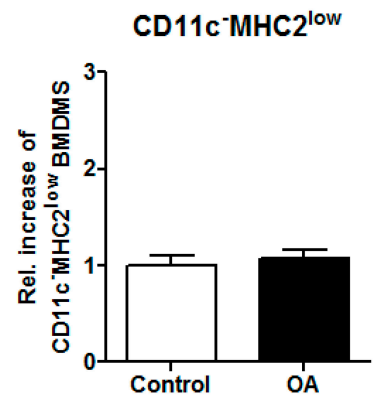

C

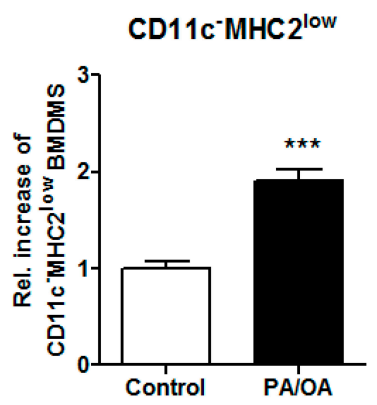

Figure 5. Free fatty acid PA induce the $\mathrm{CD}_{11 c^{-} \mathrm{MHC}}{ }^{\text {low }}$ phenotype in vitro. BMDMs were stimulated in vitro with $50 \mu \mathrm{M}$ PA, $50 \mu \mathrm{M} \mathrm{OA}$ and a combination of $50 \mu \mathrm{M}$ PA and OA to induce macrophage phenotype. Flow cytometry analysis of the stimulated BMDMs to determine the induction of the $\mathrm{CD} 11 \mathrm{c}^{-} \mathrm{MHC} 2^{\text {low }}$ subset in the BMDMs after (A) PA, (B) OA and (C) PA and OA stimulation. Representative data from 3 experiments with $n=3-4$ /experiment. Data is presented as mean \pm SEM and analyzed using an unpaired Student's $t$-test. $* * * p<0.001$.

\section{DISCUSSION}

Our study reveals that the alternative M2 macrophage subset in adipose tissue of $\mathrm{LDLR}^{-/-}$mice can be subdivided into two separate subsets based on their MHC2 expression: $\mathrm{CD} 11 \mathrm{c}^{-} \mathrm{MHC} 2^{\text {high }}$ and $\mathrm{CD} 11 \mathrm{c}^{-} \mathrm{MHC} 2^{\text {low }}$ macrophages. Canonically, ATMs, like all macrophages, are subdivided in two distinct populations: inflammatory M1 macrophages and antiinflammatory or resolving M2 macrophages [19]. However, the validity of this subdivision has been called into question in many recent studies [20,21]. In fact, recent studies report many different subtypes of ATMs [2225], each of which has their own unique characteristics. We investigated the ATM subsets in the adipose tissue during obesity in $\mathrm{LDLR}^{-/-}$mice. Our results show that in the adipose tissue of lean mice, the gene expression profiles of $\mathrm{CD} 11 \mathrm{c}^{-} \mathrm{MHC} 2^{\text {high }}$ and $\mathrm{CD} 11 \mathrm{c}^{-} \mathrm{MHC} 2^{\text {low }}$ macrophages were very 
similar, indicating comparable functions. However, upon HFD the phenotype of the $\mathrm{CD} 11 \mathrm{c}^{-} \mathrm{MHC} 2^{\text {low }}$ macrophages shifted to a more inflammatory phenotype suggesting that this subset contributes to adipose tissue inflammation during obesity. Surprisingly, genes involved in antigen presentation were induced by HFD feeding in $\mathrm{CD} 11 \mathrm{c}^{-} \mathrm{MHC} 2^{\text {low }}$ ATMs. It should be noted that the $\mathrm{CD} 11 \mathrm{c}^{-} \mathrm{MHC} 2^{\text {low }}$ subset comprises $6-7 \%$ of the stromal vascular fraction whereas the $\mathrm{CD} 11 \mathrm{c}^{-} \mathrm{MHC} 2^{\text {high }}$ and $\mathrm{CD} 11 \mathrm{c}^{+}$ subset represent $15 \%$ and $35 \%$ respectively. Therefore, on one hand, the changes in gene expression profile of the $\mathrm{CD} 11 \mathrm{c}^{-} \mathrm{MHC} 2^{\text {low }}$ subset will have a smaller impact due to their low percentage in the vAT as compared to the other subsets. On the other hand, small transcriptional changes in the $\mathrm{CD}_{11 \mathrm{C}^{+}}$ATM subset could have bigger effects since they are more abundant in the vAT.

We showed that the $\mathrm{CD}_{11 \mathrm{c}^{-} \mathrm{MHC}}{ }^{\text {low }}$ ATM subset was able to phagocytose as we were able to deplete them using clodronate liposomes. Clodronate liposomes are known to selectively deplete phagocytosing macrophages from organs and tissue [16,26], confirming that this is indeed a macrophage subset. To confirm whether the $\mathrm{CD} 11 \mathrm{c}^{-} \mathrm{MHC} 2^{\text {low }}$ subset is more potent in antigen processing, we determined the uptake and processing of DQ-OVA as a measure of antigen processing capacity. Our results revealed that during obesity, the ability to take up and process DQOVA was increased in CD11 $\mathrm{c}^{-} \mathrm{MHC} 2^{\text {low }}$ ATMs but was not changed in the CD11 ${ }^{-}$MHC2 ${ }^{\text {high }}$ ATMs, CD11 $\mathrm{c}^{+}$ATMs and the dendritic cells. Together with the unaltered cytokine profile in the plasma, our data do not support T-cell specific changes in the plasma and vAT after HFD. A previous study by Morris et al. showed that obesity in mice resulted in an increase in MHC2 levels, which was more prominent on $\mathrm{CD} 11 \mathrm{c}^{+}$compared to $\mathrm{CD} 11 \mathrm{c}^{-}$ATMs. However, it should be noted that in this study CD11 ${ }^{-}$ATMs were not subdivided based on MHC2 surface expression, making a direct comparison with our data impossible. Moreover, in contrast with our data, Morris et al. found an increase of T-cell co-stimulatory molecules on ATMs in vAT [27]. Yet, it remains unclear whether self-antigens are derived from the obese adipose. In turn, Porsche et al. revealed that dendritic cells in the adipose tissue are more potent activators of $\mathrm{CD} 4^{+} \mathrm{T}$-cells compared to ATMs and that blocking $\mathrm{CD} 4^{+}$T-cell activation in AT by reducing MHC2 on dendritic cells does not affect chronic low grade inflammation in adipose tissue with obesity [28]. Together, these results suggest that ATMs induce inflammation in the obese adipose tissue independent of their capacity to present antigen to T-cells.

The CD11 $\mathrm{c}^{-} \mathrm{MHC} 2^{\text {low }}$ subset of ATMs may have been be overlooked by previous researchers investigating ATM subsets. Rajbhandari et al. performed single cell sequencing on the SVF isolated from murine adipose tissue and revealed three subsets of macrophages after clustering analysis [29]. Although they do not go more into detail on these three macrophage subsets, it could be plausible that it divides the $\mathrm{CD} 11 \mathrm{c}^{+}, \mathrm{CD} 11 \mathrm{c}^{-} \mathrm{MHC} \mathrm{2}^{\text {high }}$ and $\mathrm{CD} 11 \mathrm{c}^{-} \mathrm{MHC} 2^{\text {low }}$ subsets into three unique clusters. Weinstock et al. 
also performed single cell sequencing on $\mathrm{CD} 45^{+}$immune cells isolated from the vAT from lean, obese and calorie restricted mice. Data analysis revealed that over $50 \%$ of the immune cells in the vAT are macrophages and they could be clustered into 7 distinct clusters with differences in metabolic and inflammatory functions [30], revealing a great heterogeneity in macrophage subsets in the vAT. In addition to singe cell sequencing data, it has been reported that gating strategies based on CD11c expression may cause relevant subsets to be overlooked. Hill et al. report the existence of $\mathrm{CD}^{+}$and $\mathrm{Ly}_{6 \mathrm{c}^{+}}$ATMs which form functionally distinct ATM subsets, but within these subsets, there is a highly heterogeneous distribution of CD11c expression [24]. In our microarray dataset, we find 3.34 fold higher CD9 expression in the CD11 $\mathrm{c}^{+}$ATM subset

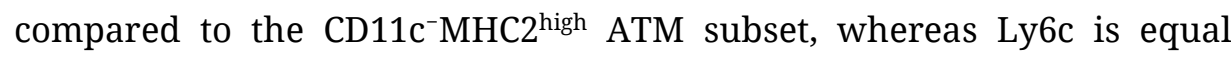

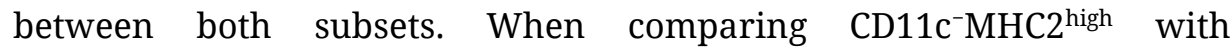
CD11 ${ }^{-} \mathrm{MHC}^{\text {low }}$ ATMs, we find 2.1 fold higher expression of CD9 in CD11 $\mathrm{C}^{-} \mathrm{MHC}^{\text {low }}$ ATMs. This increase in CD9 expression together with the inflammatory phenotype suggests that the $\mathrm{CD} 11 \mathrm{c}^{-} \mathrm{MHC} 2^{\text {low }}$ ATMs starts resembling the $\mathrm{CD} 11 \mathrm{c}^{+} \mathrm{ATM}$ subset in HFD conditions. Silva et al. identified 4 distinct ATM subsets in steady state and after chronic HFD, though unfortunately they also did not observe a CD11 $\mathrm{c}^{-} \mathrm{MHC} 2^{\text {low }}$ ATM subset [31]. These data by other groups illustrate the difficulty of establishing gating strategies that accurately recapitulate ATM subsets in vivo and that even unbiased methods, like single cell sequencing do not provide definitive answers with respect to existing ATM populations.

There has been some debate on whether ATMs expand in the adipose tissue due to local proliferation or whether they are solely recruited from the bone marrow. We have determined the origin of this novel ATM subset by making use of a bone marrow transplantation strategy in which CD45.1 donor BM cells were injected into lethally irradiated CD45.2 acceptor mice. CD45.1 donor BM cells will spontaneously repopulate the bone marrow of the irradiated acceptor mice. Tissue resident inflammatory cells will be CD45.2 allowing to discriminate between bone marrow-derived and tissue resident immune cells. The results of the bone marrow transplantation experiment show that, in the steady state, monocytes and CD11 $\mathrm{c}^{+}$ATMs in vAT are rapidly replaced by cells from the bone marrow. However, half of the $\mathrm{CD} 11 \mathrm{c}^{-} \mathrm{MHC} 2^{\text {low }}$ ATMs remain of $\mathrm{CD} 45.2$ origin, suggesting that there is slower cell turnover within this subset. Alternatively, we cannot exclude that these cells are more radioresistant than the other populations. Upon HFD, there is a massive increase in bone marrow recruited ATMs in the vAT. This increase in bone marrow origin ATMs was seen after five weeks of HFD and for the three subsets. Interestingly, the $\mathrm{CD} 11 \mathrm{c}^{-} \mathrm{MHC} 2^{\text {low }}$ subset rapidly accumulated in the adipose tissue after 10 days of HFD and remained elevated after 5 weeks HFD. We also revealed that this subset increases even further with prolonged HFD (16 weeks). In our study, it is difficult to determine the location of the ATM subsets in the adipose tissue, which would also be of great importance concerning their function in the 
tissue. Based on the microarray data, we could not find a marker specific enough to distinguish the $\mathrm{CD} 11 \mathrm{c}^{-} \mathrm{MHC} 2^{\text {low }}$ subset from the other ATM subset ( $\mathrm{CD} 11 \mathrm{c}^{-} \mathrm{MHC} 2^{\text {high}}$ ) using immunohistochemistry. Relying on the absence of CD11c, presence of $\mathrm{f} 4 / 80$ and reduced MHC2 expression makes it difficult to separate these two subsets during immunohistochemical staining of adipose tissue. Future studies using reporter mice or knock-out models may resolve this issue. Our data confirms previous work of Weisberg et al. which demonstrated that the accumulation of ATMs in the obese adipose tissue was due to an increased influx of bone marrowderived precursors [32]. Nevertheless, we cannot exclude the possibility of local proliferation of ATMs after recruitment from the bone marrow as it has been reported that local proliferation of ATMs during obesity contributes to the accumulation of ATMs [33,34]. Our data show that $\mathrm{CD}_{11 \mathrm{c}^{-} \mathrm{MHC}}{ }^{\text {high }}$ ATMs, although their accumulation seemed to originate from bone marrow precursors, displayed upregulation of genes involved in DNA replication and cell cycle implicating a proliferative phenotype of the recruited cells. Although Amano et al. did not observe differences in proliferation rates between $\mathrm{CD} 11 \mathrm{c}^{+}$and $\mathrm{CD} 11 \mathrm{c}^{-}$ATM subsets, our data are in line with the results of Haase et al, showing that proliferating cells preferentially showed M2 polarization. However, since we did not determine local proliferation by Ki67 staining and EdU or BrdU incorporation these transcriptomic results should be interpreted with care. Moreover, it could be speculated that the irradiation treatment, due to cell death, triggers monocyte influx from the bone marrow upon HFD which will normally not be induced by the HFD. It is known that circulating monocytes will fill the empty macrophage niche in the tissues after depletion [35,36]. Future experiments using shielding of the adipose tissue during irradiation, preserving tissue-resident ATMs in combination with tracer studies may resolve these pitfalls. Nevertheless, our experiments do suggest differences in the tissue residence time and recruitment of the different macrophage subsets.

The appearance of the $\mathrm{CD} 11 \mathrm{c}^{-} \mathrm{MHC}{ }^{\text {low }}$ ATM subset in obese vAT raises the question which factors drive the $\mathrm{MHC}{ }^{\text {low }}$ phenotype during obesity. FFAs are known to be increased during obesity. In human adipose tissue, OA is the most abundant FFA, whereas PA is the second most abundant [10]. Moreover, PA and OA are the major FFA types in lard, which was the main component of the HFD used in our in vivo experiments. Therefore, we selected $\mathrm{PA}$ and $\mathrm{OA}$ to investigate the potential to induce the CD11 ${ }^{-}$MHC2 ${ }^{\text {low }}$ phenotype in BMDMs. Both FFAs are documented to have an effect on macrophages; PA has inflammatory effects [37] whereas OA was able to induce arginase 1 expression, a hallmark of M2 activation, in RAW 264.7 macrophages in vitro [38]. We found that PA and the combination of $\mathrm{PA}$ and $\mathrm{OA}$ was able to induce the $\mathrm{CD} 11 \mathrm{c}^{-} \mathrm{MHC} 2^{\text {low }}$ phenotype in BMDMs. FFAs were previously shown to regulate the macrophage content of the adipose tissue. Kostelli et al. revealed that increased lipolysis (release of FFA) in the adipose tissue, which also occurs 
during weight loss, results in increased CD11 $\mathrm{c}^{-}$ATMs in the adipose tissue [18]. Future studies are needed to investigate whether or not this increase in CD11 $\mathrm{c}^{-}$ATMs represents accumulation of CD11 $\mathrm{c}^{-} \mathrm{MHC} 2^{\text {low }}$ ATMs.

\section{CONCLUSIONS}

Our data shows that $\mathrm{CD} 11 \mathrm{c}^{-}$M2 ATMs in mouse adipose tissue consist of two separate populations with its own specific functions. These $\mathrm{CD}_{11 \mathrm{c}^{-}}$ ATMs can be subdivided into two distinct subsets: $\mathrm{CD} 11 \mathrm{c}^{-} \mathrm{MHC} 2^{\text {high }}$ and CD11 $\mathrm{c}^{-} \mathrm{MHC} 2^{\text {low }}$. Microarray data shows that both subsets have a different phenotype with $\mathrm{CD} 11 \mathrm{c}^{-} \mathrm{MHC} 2^{\text {low }}$ ATMs having a more pro-inflammatory phenotype compared to the classic M2 phenotype attributed to $\mathrm{CD}^{-11 \mathrm{c}^{-}}$ ATMs. We reveal that ATMs are recruited from the bone marrow after lethal irradiation. Yet, $\mathrm{CD} 11 \mathrm{c}^{-} \mathrm{MHC} 2^{\text {low }}$ ATMs also remain in the tissue after irradiation, suggesting less cell turnover. Moreover, our data shows that FFAs PA is able to induce the $\mathrm{CD} 11 \mathrm{c}^{-} \mathrm{MHC} 2^{\text {low }}$ phenotype in vitro in BMDMs, suggesting that the microenvironment of the adipose tissue contributes to the phenotype of the ATMs. This subset of ATMs increases in the adipose tissue during inflammation and could contribute to inflammatory-related diseases such as diabetes. Our data indicates that previous research on M2 macrophages in the murine adipose tissue disregarded the inflammatory function of the $\mathrm{CD} 11 \mathrm{c}^{-} \mathrm{MHC} 2^{\text {low }}$ ATMs which could influence research results. In addition, future research is needed to elucidate the contribution of this specific subset to obesity-related diseases and for translation into the human situation.

\section{SUPPLEMENTARY MATERIAL}

The supplementary material is available online at https://doi.org/10.20900/immunometab20200014.

\section{DATA AVAILABILITY}

The dataset of the study is available from the authors upon reasonable request.

\section{AUTHOR CONTRIBUTIONS}

KW designed the studies. KW, SW, EW, JvdG and MB performed the in vivo experiments. AT performed the in vitro experiments. KW, SW, SC and MB analyzed the data. SW, KW, CS and EB wrote the manuscript.

\section{CONFLICTS OF INTEREST}

The authors declare that they have no conflicts of interest.

\section{FUNDING}

The Netherlands Organization for Scientific Research (NWO) (Veni 916.12.056), the Netherlands Heart Foundation (2013T143) and a Seventh Framework Program (FP7) (CIG 322070) to KW. 


\section{ACKNOWLEDGMENTS}

We would like to thank Jarno van Wegberg and Maria Vroomen for their technical assistance during the experiments.

\section{REFERENCES}

1. Mokdad AH, Ford ES, Bowman BA, Dietz WH, Vinicor F, Bales VS, et al. Prevalence of obesity, diabetes, and obesity-related health risk factors, 2001. JAMA. 2003;289(1):76-9.

2. Bedogni G, Miglioli L, Masutti F, Tiribelli C, Marchesini G, Bellentani S. Prevalence of and risk factors for nonalcoholic fatty liver disease: the Dionysos nutrition and liver study. Hepatology. 2005;42(1):44-52.

3. Ohman MK, Wright AP, Wickenheiser KJ, Luo W, Eitzman DT. Visceral adipose tissue and atherosclerosis. Curr Vasc Pharmacol. 2009;7(2):169-79.

4. Donath MY. Targeting inflammation in the treatment of type 2 diabetes: time to start. Nat Rev Drug Discov. 2014;13(6):465-76.

5. Biessen EAL, Wouters K. Macrophage complexity in human atherosclerosis: opportunities for treatment? Curr Opin Lipidol. 2017;28(5):419-26.

6. Boutens L, Stienstra R. Adipose tissue macrophages: going off track during obesity. Diabetologia. 2016;59(5):879-94.

7. Tailleux A, Wouters K, Staels B. Roles of PPARs in NAFLD: potential therapeutic targets. Biochim Biophys Acta. 2012;1821(5):809-18.

8. Bijnen M, Josefs T, Cuijpers I, Maalsen CJ, van de Gaar J, Vroomen M, et al. Adipose tissue macrophages induce hepatic neutrophil recruitment and macrophage accumulation in mice. Gut. 2018;67(7):1317-27. doi: 10.1136/gutjnl-2016-313654

9. Wentworth JM, Naselli G, Brown WA, Doyle L, Phipson B, Smyth GK, et al. Pro-

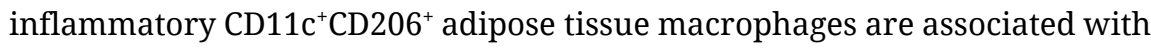
insulin resistance in human obesity. Diabetes. 2010;59(7):1648-56.

10. Hodson L, Skeaff CM, Fielding BA. Fatty acid composition of adipose tissue and blood in humans and its use as a biomarker of dietary intake. Prog Lipid Res. 2008;47(5):348-80.

11. Gordon E. Non-Esterified Fatty Acids in the Blood of Obese and Lean Subjects. Am J Clin Nutrit. 1960;8(5):740-7.

12. Reaven GM, Hollenbeck C, Jeng CY, Wu MS, Chen YD. Measurement of plasma glucose, free fatty acid, lactate, and insulin for $24 \mathrm{~h}$ in patients with NIDDM. Diabetes. 1988;37(8):1020-4.

13. Kennedy AJ, Ellacott KL, King VL, Hasty AH. Mouse models of the metabolic syndrome. Dis Model Mech. 2010;3(3-4):156-66.

14. van Bussel BC, Ferreira I, van de Waarenburg MP, van Greevenbroek MM, van der Kallen CJ, Henry RM, et al. Multiple inflammatory biomarker detection in a prospective cohort study: a cross-validation between wellestablished single-biomarker techniques and an electrochemiluminescensebased multi-array platform. PLoS One. 2013;8(3):e58576.

15. Lumeng CN, Bodzin JL, Saltiel AR. Obesity induces a phenotypic switch in adipose tissue macrophage polarization. J Clin Invest. 2007;117(1):175-84. 
16. van Rooijen N, Hendrikx E. Liposomes for specific depletion of macrophages from organs and tissues. Methods Mol Biol. 2010;605:189-203.

17. Bijnen M, Josefs T, Cuijpers I, Maalsen CJ, van de Gaar J, Vroomen M, et al. Adipose tissue macrophages induce hepatic neutrophil recruitment and macrophage accumulation in mice. Gut. 2018;67(7):1317-27.

18. Kosteli A, Sugaru E, Haemmerle G, Martin JF, Lei J, Zechner R, et al. Weight loss and lipolysis promote a dynamic immune response in murine adipose tissue. J Clin Invest. 2010;120(10):3466-79.

19. Mantovani A, Sica A, Locati M. Macrophage polarization comes of age. Immunity. 2005;23(4):344-6.

20. Martinez FO, Gordon S. The M1 and M2 paradigm of macrophage activation: time for reassessment. F1000Prime Rep. 2014;6:13.

21. Mosser DM, Edwards JP. Exploring the full spectrum of macrophage activation. Nature Rev Immunol. 2008;8(12):958-69.

22. Zeyda M, Gollinger K, Kriehuber E, Kiefer FW, Neuhofer A, Stulnig TM. Newly identified adipose tissue macrophage populations in obesity with distinct chemokine and chemokine receptor expression. Int J Obes. 2010;34(12):168494.

23. Eto H, Ishimine H, Kinoshita K, Watanabe-Susaki K, Kato H, Doi K, et al. Characterization of human adipose tissue-resident hematopoietic cell populations reveals a novel macrophage subpopulation with CD34 expression and mesenchymal multipotency. Stem Cells Dev. 2013;22(6):985-97.

24. Hill DA, Lim HW, Kim YH, Ho WY, Foong YH, Nelson VL, et al. Distinct macrophage populations direct inflammatory versus physiological changes in adipose tissue. Proc Natl Acad Sci U S A. 2018;115(22):E5096-105.

25. Kratz M, Coats BR, Hisert KB, Hagman D, Mutskov V, Peris E, et al. Metabolic dysfunction drives a mechanistically distinct proinflammatory phenotype in adipose tissue macrophages. Cell Metab. 2014;20(4):614-25.

26. Kassim SH, Rajasagi NK, Zhao X, Chervenak R, Jennings SR. In vivo ablation of CD11c-positive dendritic cells increases susceptibility to herpes simplex virus type 1 infection and diminishes NK and T-cell responses. J Virol. 2006;80(8):3985-93.

27. Morris DL, Cho KW, Delproposto JL, Oatmen KE, Geletka LM, MartinezSantibanez G, et al. Adipose tissue macrophages function as antigenpresenting cells and regulate adipose tissue $\mathrm{CD}^{+} \mathrm{T}$ cells in mice. Diabetes. 2013;62(8):2762-72.

28. Porsche CE, Delproposto JB, Patrick E, Zamarron BF, Lumeng CN. Adipose tissue dendritic cell signals are required to maintain $\mathrm{T}$ cell homeostasis and obesity-induced expansion. Mol Cell Endocrinol. 2020;505:110740.

29. Rajbhandari P, Arneson D, Hart SK, Ahn IS, Diamante G, Santos LC, et al. Single cell analysis reveals immune cell-adipocyte crosstalk regulating the transcription of thermogenic adipocytes. Elife. 2019;8:e49501. doi: 10.7554/eLife.49501

30. Weinstock A, Brown EJ, Garabedian ML, Pena S, Sharma M, Lafaille J, et al. Single-Cell RNA Sequencing of Visceral Adipose Tissue Leukocytes Reveals that Caloric Restriction Following Obesity Promotes the Accumulation of a 
Distinct Macrophage Population with Features of Phagocytic Cells. Immunometabolism. Immunometabolism. 2019;1:e190008. https://doi.org/10.20900/immunometab20190008

31. Silva HM, Bafica A, Rodrigues-Luiz GF, Chi J, Santos PDA, Reis BS, et al. Vasculature-associated fat macrophages readily adapt to inflammatory and metabolic challenges. J Exp Med. 2019;216(4):786-806.

32. Weisberg SP, McCann D, Desai M, Rosenbaum M, Leibel RL, Ferrante AW Jr. Obesity is associated with macrophage accumulation in adipose tissue. J Clin Invest. 2003;112(12):1796-808.

33. Amano SU, Cohen JL, Vangala P, Tencerova M, Nicoloro SM, Yawe JC, et al. Local proliferation of macrophages contributes to obesity-associated adipose tissue inflammation. Cell Metab. 2014;19(1):162-71.

34. Haase J, Weyer U, Immig K, Kloting N, Bluher M, Eilers J, et al. Local proliferation of macrophages in adipose tissue during obesity-induced inflammation. Diabetologia. 2014;57(3):562-71.

35. Mildner A, Schmidt H, Nitsche M, Merkler D, Hanisch UK, Mack M, et al. Microglia in the adult brain arise from Ly-6ChiCCR2+ monocytes only under defined host conditions. Nat Neurosci. 2007;10(12):1544-53.

36. Sakai M, Troutman TD, Seidman JS, Ouyang Z, Spann NJ, Abe Y, et al. LiverDerived Signals Sequentially Reprogram Myeloid Enhancers to Initiate and Maintain Kupffer Cell Identity. Immunity. 2019;51(4):655-70.e8.

37. Weatherill AR, Lee JY, Zhao L, Lemay DG, Youn HS, Hwang DH. Saturated and polyunsaturated fatty acids reciprocally modulate dendritic cell functions mediated through TLR4. J Immunol. 2005;174(9):5390-7.

38. Pardo V, Gonzalez-Rodriguez A, Guijas C, Balsinde J, Valverde AM. Opposite cross-talk by oleate and palmitate on insulin signaling in hepatocytes through macrophage activation. J Biol Chem. 2015;290(18):11663-77.

How to cite this article:

Wetzels S, Bijnen M, Wijnands E, van de Gaar J, Tan A, Coort S, et al. CD11c-MHC2 ${ }^{\text {low }}$ Macrophages Are a New Inflammatory and Dynamic Subset in Murine Adipose Tissue. Immunometabolism. 2020;2(2):e200015. $\underline{\text { https://doi.org/10.20900/immunometab20200015 }}$ 